\title{
Occupational safety issues related to computer equipment installation, maintenance and use
}

\author{
Daniel Onuț Badea ${ }^{1}$, Doru Costin Darabont ${ }^{1 *}$, Dominic Bucerzan ${ }^{2}$, Alina Trifu ${ }^{1}$, Eduard \\ Smîdu $^{3}$, Eugenia Bulboacă ${ }^{3}$, and Vergilică Haralambie ${ }^{3}$ \\ ${ }^{1}$ INCDPM Institutul National de Cercetare-Dezvoltare pentru Protecțía Muncii” Alexandru Darabont” \\ București, B-dul Ghencea 35A, România \\ ${ }^{2}$ SC BB Computer SRL, Str. Nicolae Bălcescu 12, Arad, Romania \\ ${ }^{3}$ University Politehnica of Bucharest, Splaiul Independenţei nr. 313, Sector 6, Romania
}

\begin{abstract}
This paper presents the findings of an ongoing INCDPM project developed in collaborations with BB Computers that addresses the occupational safety issues related to computer equipment installation, maintenance and use, with emphasis on risk identification. The method used was The Preferred Reporting Items for Systematic reviews and MetaAnalyses (PRISMA). Using the chart flow and the list of items of this method, a literature search was conducted in Science Direct Freedom Collection, Elsevier database, Web of Science - Core Collection, Springer Link Journals. Keywords such as occupational risks, computer equipment installation, computer maintenance were used to retrieve relevant studies which explicitly reported on occupational risks related to computer equipment installation, maintenance and use. The literature search yielded 900 references, of which 20 articles were selected for full-text screening as specified by the inclusion criteria, and ultimately 10 were included in this review. It was developed an extensive and comprehensive list of occupational risks related to computer equipment installation, maintenance and use. After a classification of the equipment in calculation and processing equipment, electronic displays, printer, special printers network equipment the main risks identified in all categories mentioned above are as follows: electric shock, stress, high workload, slips and trips.
\end{abstract}

\section{Introduction}

Computer equipment installation, maintenance and use pose a range of occupational hazards such as: injuries related to the handling of heavy objects; accidents related to the overturning of stacked boxes; accidents related to the transport of insufficiently insured objects against overturning; electric shock due to damaged and uninsulated cables; burns on contact with hot components; electric shock due to the intervention of unskilled persons inside the computer. This paper presents the findings of an ongoing project developed by INCDPM in collaborations with SC BB Computer SRL that addresses the occupational

\footnotetext{
${ }^{*}$ Corresponding author: darabont_d@yahoo.com
} 
safety issues related to computer equipment installation and maintenance, because this is main INCDPM's partner activity.

\section{Method}

For this paper it was used The Preferred Reporting Items for Systematic reviews and MetaAnalyses (PRISMA). The PRISMA has been designed primarily for systematic reviews of studies that evaluate the effects of health interventions, irrespective of the design of the included studies. However, the checklist items are applicable to reports of systematic reviews evaluating other non-health-related interventions (for example, social or educational interventions), and many items are applicable to systematic reviews with objectives other than evaluating interventions [1]. The PRISMA 2020 items are relevant for mixed-methods systematic reviews (which include quantitative and qualitative studies).

A literature search was conducted in ScienceDirect Freedom Collection, Elsevier database, Web of Science - Core Collection, Clarivate Analytics, Scopus, SpringerLink Journals. Keywords such as occupational risks in computer equipment installation and maintenance, hazards in installation and maintenance of calculation and processing equipment, electronic displays, printer, special printers network equipment were used to retrieve relevant studies which explicitly reported on occupational risks related to computer equipment installation and maintenance. The searches were limited to English and Romanian languages only.

To complete the PRISMA diagram it was print out a copy of the diagram to use alongside the searches. It is most efficient to search databases individually, so it was printed out a copy for each database searched, plus a copy for the totals. For each database it was entered each key search term individually, then there were combined all the search terms in the different combinations using Boolean operators like AND OR as appropriate. We applied all our limits (such as years of search, full-text only, English language only and so on). Once all search terms have been combined and we have applied all relevant limits, we obtained a number of records or articles and entered this in the top left box of the PRISMA flow chart for each database. Because we have searched databases individually, we add all the 'records identified' up and fill this total number in the PRISMA flow diagram. This process of adding up the number of records in individual database searches to a total it was repeated at each step. For the articles identified through other sources than databases (like manual searches through reference lists of articles found, or search engines like Google Scholar), it was entered the total number of records in the box on the top right of the flow diagram. To avoid reviewing duplicate articles, it was removed manually any articles that appear more than once by going through all the records or articles found in the database. The number of records left after the removal of the duplicates was entered in the second box from the top.

The titles and abstracts of the search results were screened independently by all authors with discrepancies discussed and resolved.

Articles were eligible for full-text screening if the title and/or abstract mentioned occupational risks in computer equipment installation and maintenance. Full-texts were screened for inclusion by all authors disagreements resolved by discussion. Articles were included in this systematic review if they reported on occupational risks in computer equipment installation and maintenance. Research studies that made use of previously collected or administrative data were also acceptable if they satisfied other criteria. Studies were excluded if they were published before 2000 . 


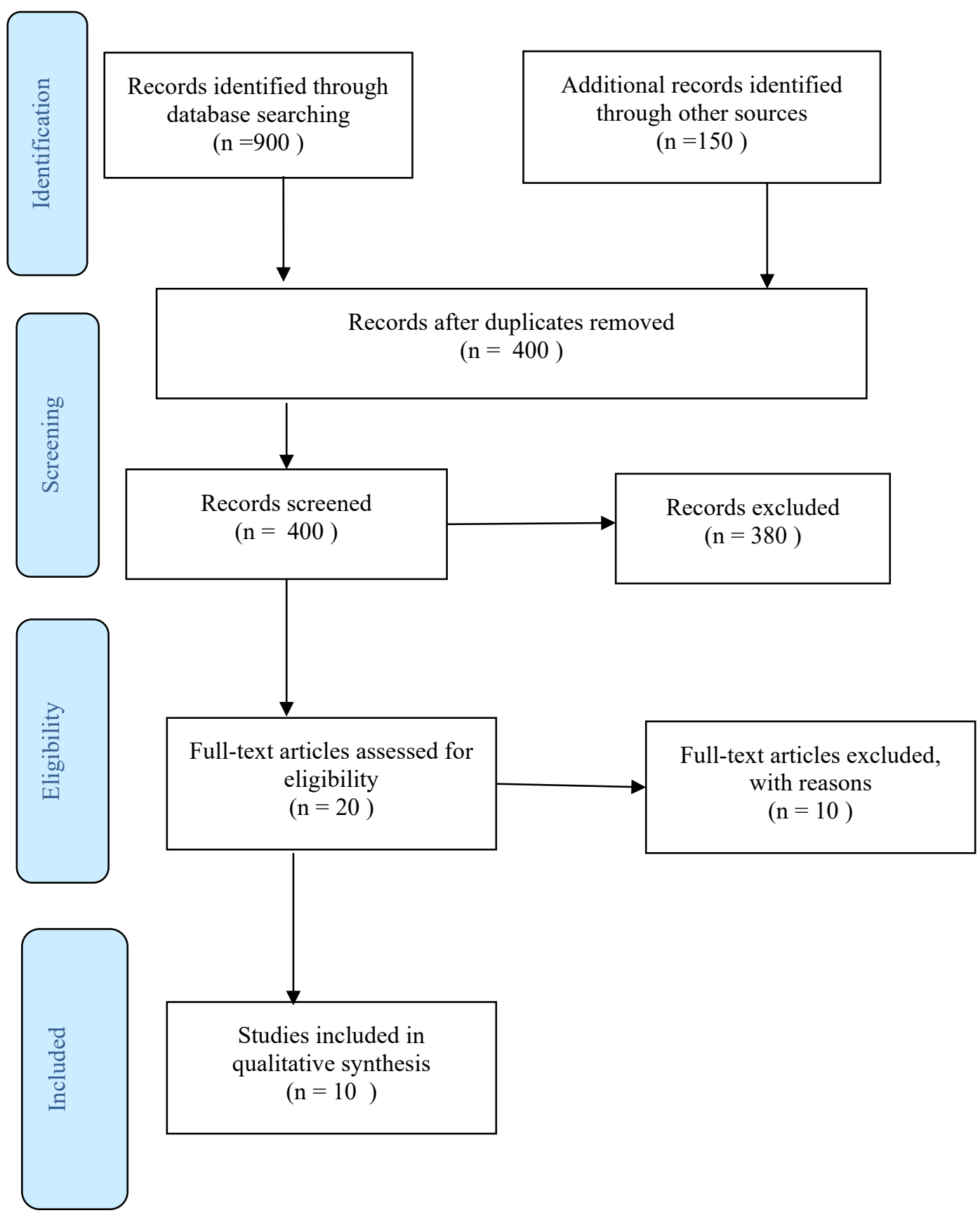

Fig. 1. PRISMA flow diagram

\section{Results and discussion}

The literature search yielded 900 references, of which 20 articles were selected for full-text screening as specified by the inclusion criteria, and ultimately 10 were included in this 
review (Fig. 1). It was developed an extensive and comprehensive list of occupational risks related to computer equipment installation, maintenance and use.

After a classification of the equipment in calculation and processing equipment, electronic displays, printer, special printers network equipment the main risks identified in all categories mentioned above are as follows: electric shock due to damaged and uninsulated cables; failure of improperly installed and secured equipment; non-ionizing radiation due to prolonged exposure in the vicinity of Wi-Fi antennas, accidents related to the overturning of stacked boxes; accidents related to the transport of insufficiently insured objects against overturning; overvoltage induced in the network cables; falling from a height in the case of equipment mounted in high positions.

The risks were categorized according to equipment: desktop computers, laptop computers, server type computers and supercomputers, TVs, computer monitors, video projectors, digital display systems, interactive kiosks, laser printers and multifunction printers, inkjet printers, Braille printer, UV printer, 3D printer, network equipment.

In the table below we summarised the main occupational risks related to handling, installation and maintenance of computer equipment.

Table 1. Main occupational risks related to handling, installation and maintenance of computer equipment

\begin{tabular}{|c|c|}
\hline $\begin{array}{c}\text { Type of } \\
\text { equipment }\end{array}$ & Identified risks \\
\hline $\begin{array}{c}\text { Network } \\
\text { equipment: } \\
\text { Routers, } \\
\text { Repeaters, } \\
\text { Hubs, Switches, } \\
\text { Bridge }\end{array}$ & $\begin{array}{l}\text { a) Handling and installation may involve: accidents } \\
\text { related to the overturning of stacked boxes; accidents } \\
\text { related to the transport of insufficiently insured objects } \\
\text { against overturning; [5] overvoltage induced in the } \\
\text { network cables; falling from a height in the case of } \\
\text { equipment mounted in high positions. [6] } \\
\text { b) At installation, commissioning, use and maintenance } \\
\text { there are risks related to: electric shock due to damaged } \\
\text { and uninsulated cables; failure of improperly installed } \\
\text { and secured equipment; non-ionizing radiation due to } \\
\text { prolonged exposure in the vicinity of Wi-Fi } \\
\text { antennas.[2] }\end{array}$ \\
\hline Braille printers & $\begin{array}{l}\text { a) Handling and installation may involve: accidents } \\
\text { related to the overturning of stacked boxes; related to } \\
\text { the transport of insufficiently insured objects against } \\
\text { overturning; overvoltage induced in the network } \\
\text { cables.[3] } \\
\text { b) At installation, commissioning, use and maintenance } \\
\text { there are risks related to: electric shock due to damaged } \\
\text { and uninsulated cables; electric shock due to the } \\
\text { intervention of unskilled persons on the equipment; } \\
\text { failure of improperly installed and secured equipment; } \\
\text { excessive noise of } 80 \mathrm{~dB} \text { without protective } \\
\text { enclosure.[4] }\end{array}$ \\
\hline UV printers & $\begin{array}{l}\text { a) Handling and installation may involve: accidents } \\
\text { related to the overturning of stacked boxes; related to } \\
\text { the transport of insufficiently insured objects against } \\
\text { overturning; overvoltage induced in the network } \\
\text { cables[7]. } \\
\text { b) At installation, commissioning, use and maintenance } \\
\text { there are risks related to: electric shock due to damaged } \\
\text { and uninsulated cables; electric shock due to the } \\
\text { intervention of unskilled persons on the equipment; } \\
\text { failure of improperly installed and secured equipment; }\end{array}$ \\
\hline
\end{tabular}




\begin{tabular}{|c|c|}
\hline \multirow[b]{2}{*}{$3 \mathrm{D}$ printers } & $\begin{array}{c}\text { ultraviolet (non-ionizing) radiation if used without a } \\
\text { shield [8]; blows and crushing if intervened during } \\
\text { operation. }\end{array}$ \\
\hline & $\begin{array}{l}\text { a) Handling and installation may involve: accidents } \\
\text { related to the overturning of stacked boxes; related to } \\
\text { the transport of insufficiently insured objects against } \\
\text { overturning; overvoltage induced in the network cables } \\
\text { b) At installation, commissioning, use and maintenance } \\
\text { there are risks related to: electric shock due to damaged } \\
\text { and uninsulated cables; electric shock due to the } \\
\text { intervention of unskilled persons on the equipment; } \\
\text { falling of improperly installed and secured equipment; } \\
\text { ultraviolet (non-ionizing) radiation if used without a } \\
\text { shield; thermal burns when heated surfaces are reached } \\
\text { [9]; toxic gases and odours produced by overheating of } \\
\text { some polymers. [11] }\end{array}$ \\
\hline $\begin{array}{l}\text { Laser Printers } \\
\text { and } \\
\text { Multifunction } \\
\text { Printers }\end{array}$ & $\begin{array}{l}\text { a) Handling and installation may involve: accidents } \\
\text { related to the overturning of stacked boxes; related to } \\
\text { the transport of insufficiently insured objects against } \\
\text { overturning; overvoltage induced in the network cables } \\
\text { b) At installation, commissioning, use and maintenance } \\
\text { there are risks related to: electric shock due to damaged } \\
\text { and uninsulated cables; electric shock due to the } \\
\text { intervention of unskilled persons on the equipment; } \\
\text { falling of improperly installed and secured equipment; } \\
\text { thermal burns when changing toner cartridges } \\
\text { incorrectly; risks related to damage to toner tanks. [10] }\end{array}$ \\
\hline $\begin{array}{l}\text { TVs, computer } \\
\text { monitors, video } \\
\text { projectors, } \\
\text { digital display } \\
\text { systems, } \\
\text { interactive } \\
\text { kiosks }\end{array}$ & $\begin{array}{l}\text { a) Handling and installation may involve: accidents } \\
\text { related to the overturning of stacked boxes; related to } \\
\text { the transport of insufficiently insured objects against } \\
\text { overturning; overvoltage induced in the network cables; } \\
\text { risk of falling from a height, when installing monitors } \\
\text { on the wall or at a height. } \\
\text { b) At installation, commissioning, use and maintenance } \\
\text { there are risks related to: electric shock due to damaged } \\
\text { and uninsulated cables; eye conditions due to prolonged } \\
\text { use and incorrectly adjusted brightness; electric shock } \\
\text { due to the intervention of unskilled persons inside the } \\
\text { equipment; falling of improperly installed and secured } \\
\text { equipment; thermal or chemical burns due to incorrect } \\
\text { handling of cooling media used for air conditioning; } \\
\text { cuts and injuries when using accidentally damaged or } \\
\text { vandalized equipment. }\end{array}$ \\
\hline $\begin{array}{c}\text { Desktop } \\
\text { computers, } \\
\text { laptop } \\
\text { computers, } \\
\text { server type } \\
\text { computers and } \\
\text { supercomputers }\end{array}$ & $\begin{array}{l}\text { a) Handling and installation may involve: accidents } \\
\text { related to the overturning of stacked boxes; related to } \\
\text { the transport of insufficiently insured objects against } \\
\text { overturning; overvoltage induced in the network cables; } \\
\text { b) At installation, commissioning, use and maintenance } \\
\text { there are risks related to: electric shock due to damaged } \\
\text { and uninsulated cables; burns on contact with hot } \\
\text { components; electric shock due to the intervention of } \\
\text { unskilled persons inside the computer; thermal or } \\
\text { chemical burns due to incorrect handling of cooling } \\
\text { media. }\end{array}$ \\
\hline
\end{tabular}


This extensive and comprehensive list containing main occupational risks related to handling, installation and maintenance of computer equipment will be used to develop an expert decision system. This decision support system is a system whose mission is to facilitate the activity of decision makers (managerial staff in an economic unit), at different levels of management (from oversight of technological processes to top management), in the sense of making better, more efficient and documented decisions. Such systems provide sufficient support to the decision-maker (related to occupational risks) for that decision to minimize certain risks that have been identified.

This system was designed in multi-layer architecture, to meet the support needs of decision makers. The basic layer of the system consists of an Information Tutorial System followed by an intermediate layer, a Reference System - expert system for occupational risk assessment on the basis of which the decision is adopted. The last layer, the top layer of the system is a Procedural System that includes prevention procedures and risk control measures.

\section{Conclusions}

Computer equipment installation, maintenance and use pose a range of occupational hazards such as: injuries related to the handling of heavy objects; accidents related to the overturning of stacked boxes; accidents related to the transport of insufficiently insured objects against overturning; electric shock due to damaged and uninsulated cables; burns on contact with hot components; electric shock due to the intervention of unskilled persons inside the computer. At installation, commissioning, use and maintenance there are risks related to: electric shock due to damaged and uninsulated cables; eye conditions due to prolonged use and incorrectly adjusted brightness; electric shock due to the intervention of unskilled persons inside the equipment; falling of improperly installed and secured equipment; thermal or chemical burns due to incorrect handling of cooling media used for air conditioning; cuts and injuries when using accidentally damaged or vandalized equipment.

The results presented in this paper are partial results from the project „Partnership for knowledge transfer and research development related to the assessment and prevention of occupational risks that can lead to disasters (PROC)", ID / SMIS Code 2014+: POC P_40_182 / 111954, Subsidiary contract no. 4/17.02.2020 SC BB Computer SRL.

\section{References}

1. MJ. Page, JE McKenzie, PM Bossuyt, I Boutron, TC Hoffmann, CD Mulrow, et al, Prisma systematic Reviews (open access). The PRISMA 2020 statement: an updated guideline for reporting systematic reviews. Systematic Reviews 2021;10:89.

2. G. Buica, AE Antonov, C. Beiu, D. Pasculescu, D. Remus, MATEC Web Conf. 12111006 (2017).The impact of occupational risks in the operating and maintenance activities in the energy sector, DOI: $10.1051 /$ matecconf $/ 201712111006$

3. European Commission, European statistics on accidents at work (ESAW) - methodology, Brussels, European Commission Directorate-General for Employment and Social Affairs, 2011

4. EU-OSHA - European Agency for Safety and Health at Work, European Risk Observatory, 2010 Maintenance and Occupational Safety and Health - A statistical picture

5. International Labour Office and Sectoral Activities Department; Global Dialogue Forum on Safety in the Supply Chain in Relation to Packing of Containers (2011, Geneva, Switzerland).

6. Health and Safety International - The Journal for Employee Protection, Working at Height Hazards and Control Measures, 2017 
7. Schött-Szymczak, A.; Walczak, K. Impact of Cable Configuration on the Voltage Induced in Cable Screen during Work with One-Sidedly Ungrounded Cable Screen. Energies 2021, 14, 4263. https://doi.org/10.3390/en14144263

8. Office hazards: Photocopiers, printers etc https://www.ohsrep.org.au/office_hazards_ photocopiers_printers_etc [Accessed 22 March 2021]

9. Thermal Burns, https://emedicine.medscape.com/article/1278244-overview [Accessed 22 March 2021]

10. Printing Industry Risk Management Guide - Canada, [Online].Available: https://www.travelerscanada.ca/iw-documents/canada/Man_PrintersRMG.pdf [Accessed 22 March 2021]

11. 3D Printer Safety, [Online]. Available: https://www.concordia.ca/content/dam/ concordia/services/safety/docs/EHS-DOC-148_3DPrinterSafety.pdf [Accessed 22 March 2021] 